\title{
Tertiary sector employment in Latin America: between modernity and survival
}

\author{
Jürgen Weller
}

I

the 1990s, around $90 \%$ of all new jobs in Latin America and the Caribbean arose in the tertiary sector. This article reviews the main theories about the expansion of this kind of employment, compares the recent evolution of the Latin American tertiary sector with global trends, and analyses the characteristics of the employment offered in the various branches making up the sector, as well as its underlying dynamics. The growth of employment in the Latin American tertiary sector is based on simultaneous processes of labour inclusion and exclusion. The firstnamed process reflects the growing role of some tertiary sector activities in systemic competitiveness and social reproduction, and is expressed in the generation of jobs of comparatively high productivity and quality. The second, however, is due to the pressures of the labour supply and gives rise to jobs that are usually of low productivity and quality.

Jürgen Weller

Economic Affairs Officer, Economic Development Division, Macroeconomic Analysis Unit ECLAC

œ jurgen.weller@cepal.org 


\section{I}

\section{Introduction}

The various branches of activity of the tertiary sector accounted for about $90 \%$ of the new jobs which were created in Latin America and the Caribbean in the 1990 s, and at the end of that decade they represented $55 \%$ of total employment. In spite of its great weight in the labour market, however, tertiary sector employment has been studied less than agricultural employment and much less than employment in manufacturing.

One of the reasons for this is the high level of heterogeneity of employment in the sector. On the one hand, tertiary activities play an increasingly important role in the productive and social structures - for example, in terms of systemic competitiveness and the well-being of the population - and this has resulted in a growing demand for labour. Many of these activities offer favourable potential for social and labour-related development, since they provide jobs that usually require relatively small investments of physical capital and technology, place emphasis above all on human capital, and allow small and medium-sized enterprises to operate competitively. Furthermore, the tertiary sector is the main generator of good-quality employment for women. On the other hand, however, in the tertiary sector we find most of the low-productivity, poorly paid and poor quality jobs, because of the low entry barriers to certain activities such as personal services and trade. Women account for a high proportion of this segment, too.

This article analyses the recent dynamics of employment generation in the Latin American tertiary sector. To this end, section II makes a summary analysis of the definitions, classifications and theories on employment in this sector, with special emphasis on its heterogeneity and the fact that many definitions and classifications over-simplify the processes of employment generation and do little to help in their analysis. Particular stress is laid on the importance of taking a dynamic view of this sector's contribution to employment generation.

Section III compares the empirical evidence on the evolution of tertiary sector employment at the world level and poses the question of whether Latin America and the Caribbean have special characteristics in this respect and, in particular, whether the data support the theory that there is a fundamental difference between the evolution of tertiary employment in the industrialized countries ${ }^{1}$ and that observed in the Latin American and Caribbean region (genuine versus spurious tertiarization).

In section IV it is shown that during the 1990s the great majority of new jobs arose in the tertiary sector, but many of those jobs were in low-productivity activities. At all events, there are great variations between the countries in this respect, mainly explained by differences in economic growth. There is also great heterogeneity among the different branches of the sector, so that an analysis is also made of the main characteristics of each branch and the dynamics determining employment growth. Finally, sector V presents some conclusions on the features of employment generation in the sector.
This article is based on Weller (2001), in which Nora Ruedi, Gloria Bensan, Laura Brunet and Ignacio Fiestas provided valuable collaboration and which contains additional empirical information. The views expressed here are the exclusive responsibility of the author and do not necessarily coincide with those of the organization to which he belongs.

\footnotetext{
${ }^{1}$ In this article, the category of "industrialized countries" is maintained, even though it has been argued that service activities are of growing importance in those countries, too. Be that as it may, the existence of a production structure with a relatively large, productive and homogeneous manufacturing sector continues to be an element distinguishing the countries in question, and the performance of that sector in terms of growth and productivity is a key variable for their overall economic performance (Pieper, 2000).
} 


\section{II}

\section{Definitions, classifications and theories}

\section{Definitions and classifications}

The notion of a tertiary sector arose out of the desire to classify the economic activities. At first, it was defined as a residual, i.e. it consisted of all the activities that did not belong to the primary sector (agriculture, stock-raising, forestry, fisheries, mining) or the secondary sector (manufacturing, construction). In order to make the concept more precise, efforts were later made to characterize the sector in terms of common elements. Thus, emphasis was placed on some characteristics of tertiary activities which would differentiate them from those of the primary and secondary sectors: for example, their products would be intangible, non-transferrable and perishable, so that they could not be stored, and they would also be highly labour intensive because of the limitations on replacing labour with capital and technology.

Although these specifications help to understand the differences between many services, on the one hand, and the primary and secondary sectors, on the other, they are not valid for all the activities usually classed as tertiary. Moreover, as the most recent technological changes have increased the heterogeneity of the latter, the characteristics in question are less and less useful for distinguishing the tertiary sector from other sectors. It may be noted, in particular, that many services are increasingly transferable (such as financial, medical and educational services, as well as business services such as "back office" services, data processing and consultancy). This means that the difference between tradeable products, which traditionally come mainly from the primary and secondary sectors, and tradeable goods, which are traditionally not produced by the tertiary sector and construction, is increasingly unclear. Furthermore, the new technological resources create economies of scale and, for example, can partly take the place of the teacher in education. At the same time, many services have ceased to be perishable (thanks to storage devices) and their product (knowledge, etc.) serves to accumulate human capital. Lastly, there are many services which make increasingly intensive use of capital and technology (communications satellites, for example).
Thus, the most recent trends make it difficult to define tertiary activities on the basis of a set of common characteristics. At the same time, they increase the heterogeneity of those activities (especially with regard to the use of physical capital, technology and human capital). Consequently, rather than trying to impose a non-existent homogeneity on this set of activities, it is important to differentiate it more.

For this purpose, there are various proposed classifications of services. Rubalcaba (1997, p. 29 et seq.) mentions the following: ${ }^{2}$

- Distributive services, producer services, social services, personal services (Browning and Singelmann).

- Marketable services, services provided in situ, durable services and non-durable services (Nusbaumer).

- Permanent and temporary services, reversible and irreversible services, services provided privately and collectively, non-marketed and marketed services (Ochel and Wegner).

Like the definitions mentioned earlier, some of these classifications tend to be become obsolete or at least less clear with technological change and market integration. Thus, some services change from nonmarketed to marketed or from non-durable to durable, while others do not fit clearly into the classifications. Although this does not detract from the importance of the disaggregation and reclassification efforts, the fact that the conditions and characteristics of services activities change with the passage of time highlights the importance of a dynamic perspective. ${ }^{3}$

\section{Theories: the heterogeneity of the tertiary sector}

\section{a) Genuine and spurious tertiarization}

Broadly, two main trends which increase employment in tertiary activities may be identified.

\footnotetext{
2 Other forms of differentiation have been proposed by Gershuny (1987), Bhagwati (1987), Baumol (1985) and Ryten (1999).

${ }^{3}$ Krüger (1999) gives the example of meat pies, which were traditionally prepared at home but are now more often consumed in fast food restaurants or purchased frozen in the supermarket.
} 
Firstly, in the industrialized countries the expansion of the tertiary sector is generally seen as a sign of the evolution of the productive structure and society in general. At least since the debate on the postindustrial society (Bell, 1973), it has been held that with the development of science and technology the proportion of manual and unskilled workers will go down, and most of the labour force will produce nontangible goods and services. Knowledge will become the main factor for economic growth, and education and professional qualifications will be key elements for individual well-being and upward social progress. The contribution of tertiary activities to economic growth will increase both because of their growing share in the composition of GDP and their strategic role for improving the competitiveness of enterprises in other branches and of whole economies, through systemic competitiveness. ${ }^{4}$ One expression of this trend is the outsourcing of certain activities and the subcontracting of specialized firms for the supply of particular services. ${ }^{5}$ Much of the increase in tertiary employment in the industrialized countries since World War II is due to the expansion of these activities, which require high levels of skills. In the context of globalization, these processes tend to go beyond national frontiers, since although there may not be internationally integrated labour markets, the formation of transnational networks in production structures integrates occupations carried out in different places (Castells, 1997, pp. 260-268).

In addition to the growing role of services as a result of the evolution of the production structure, there are other dynamics affecting employment in this sector which operate at the household level. In this respect, an extension of Engel's Law has been adduced as one of the reasons for the long-term upward trend in employment in the sector (Appelbaum and Schettkat, 1995): thus, just as increasing household income leads to a reduction in the share of food in their expenditure, it also later leads to their saturation with durable manufactured goods, and services then begin to represent a growing percentage of household consumption. This hypothesis has been questioned by Gershuny (1987)

\footnotetext{
${ }^{4}$ See, for example, Giarini (1995) and different contributions in Giarini (1987) and in Economía industrial (1997), Wieczorek (1995), Willke (1999), and Altenburg, Qualmann and Weller (2001, pp. 29-33). ${ }^{5}$ Obviously, apart from the strategy of exploiting the advantages of specialization, another strategy seeks to increase competitiveness through the purchase of goods and services from other firms which have lower labour costs (due to lower wages, failure to comply with labour regulations, etc.).
}

and Wieczorek (1995): as there are major constraints on increasing the productivity of personal services, while the wages paid in those activities rise together with the general wage level, their labour costs tend to increase substantially. As a result, in the industrialized countries the tendency is rather towards a decline in the importance of household services and their replacement with own-account work (do it yourself activities, cleaning) and with the purchase of goods (prepared food, new products instead of repairs to old ones). At all events, it is undeniable that as household income improves, the proportion of services in household consumption increases, not only through market transactions but also in terms of services financed through their taxes or contributions (health, education, care of old people, etc.).

The new role of tertiary activities, both in the production process itself and in a broader sense of systemic competitiveness and socio-economic wellbeing, makes it necessary to get away from old concepts which draw a distinction between productive and non-productive work and consider that services, by facilitating consumption, belong to the non-productive category. When one considers how important services such as education and health are for systemic competitiveness, it is not appropriate either to maintain a similar distinction based on a new definition, such as that business services are productive and community, social and personal services are not (Giarini, 1995). In view of the changes which have taken place, the old definitions become obsolete, and this may help to overcome some specific labour exclusions, such as the traditional equation of productive work (in primary and secondary activities) with male labour and non-productive work (in tertiary activities) with female employment. Recognition of the new role of the tertiary sector would help to overcome the cases of discrimination based on such hierarchic differentiation (Krüger, 1999).

Secondly, some services have the lowest entry barriers of all branches of activity, due to their low or non-existent requirements for capital, land, technology and human capital, which enables them to serve as a "refuge" for a labour force which cannot find employment in more productive and better paid activities. Thus, the weight of informal activities is usually greater in the tertiary than in the secondary sector. These tendencies are obviously much more marked in Latin America and the Caribbean than in the industrialized countries, so that it has been suggested that the expansion of tertiary employment in the Latin 
American and Caribbean region represents spurious tertiarization rather than what might be called the genuine version promoted by the changes in industrial societies (Pinto, 1984; Carneiro, 1994). In Latin America and the Caribbean, these tendencies are considered to have become stronger in the $1980 \mathrm{~s}$ - some authors talked about over-tertiarization, in the sense of the exhaustion of the informal sector's capacity to absorb labour (Verdera, 1994) — and according to ILO data they continued even during the 1990 s, since not only was $90 \%$ of new employment concentrated in the tertiary sector, but $70 \%$ was in lowproductivity services. This latter phenomenon has been called the "informalization of services" (Klein and Tokman, 2000, p. 16).

\section{b) The dynamics of tertiary sector heterogeneity}

In opposition to a polarized characterization of tertiary sector employment based on the differentiation between genuine and spurious tertiarization, it has been argued that also in Latin America and the Caribbean, at least up to the 1970s, there was dynamic generation of employment in skilled services which made a substantial contribution to the expansion of formal urban employment (Ramos, 1984). In this evolution, an important role was played by the marked presence of the public sector and - largely concentrated in this - of professionals of high educational level (Echeverría, 1985). As a result, up to 1980 in a group of eight countries, approximately $70 \%$ of tertiary employment was in the formal sector (Gatica, 1986). ${ }^{6}$

Comparing the Latin American evolution with the experience of the more advanced countries, Berry (1976) argues that, because of technological progress, at similar stages of development the primary and secondary sectors of Latin America and the Caribbean attained higher levels of productivity, meaning that they had less capacity to absorb labour, so that a larger percentage of employment was concentrated in the tertiary sector. Likewise adopting a historical perspective, Kaztman (1984, p. 101) holds that in Latin America, in a first phase, the increase in employment in the tertiary sector was the result of supply pressures generated by rural-urban migration, but subsequently

\footnotetext{
${ }^{6}$ In contrast with the calculations of informality in the 1990s, Gatica (1986) does not include employment in micro-enterprises in informal employment. According to this author, the trends in the 1960-1980 period were not similar among the countries studied, because in five of them the informality of the tertiary sector went down, while in the other three it went up.
}

it was due more to a close link with the industrialization process and the expansion of the access of the population to modern services.

De Oliveira and Ariza (1998, p. 112 et seq.) offer another dynamic interpretation of the evolution of employment. These authors link the different evolution of employment in the tertiary branches - according to the groups defined by Browning and Singelmann (1975) already referred to- with the different stages in the economic development of Mexico (which can be generalized, up to a certain point, to cover the economic evolution of the region as a whole), highlighting the branches which grew most because of the economic development characteristics of each stage, within the context of the overall growth of the tertiary sector:

- In the agro-export development phase, employment in personal services went down in relative importance, while employment in distributive and social services increased, as a result of growing territorial integration and growth of the public sector;

- In the first phase of the import substitution stage, employment in producer services expanded as a result of the growth and modernization of manufacturing, while it also increased in the case of personal services, in line with population growth;

- In the phase in which the import substitution model was being consolidated, employment in social services increased thanks to the growth of the public administration and investment in education and health;

- In the years of crisis and economic restructuring, there was a relative increase in personal services and trade to the detriment of social and producer services, due to the weak demand for labour by the sectors with the highest productivity and the concentration of new jobs in activities with low entry barriers.

Thus, it can be said that also in Latin America and the Caribbean, the historical evolution of tertiary employment was closely linked with the specific features of economic and social development.

In opposition to a dichotomous view - genuine tertiarization in the industrialized countries and spurious tertiarization in Latin America and the Caribbean - it may also be noted that, partly as a result of the foregoing, it has been found that the average labour productivity of tertiary activities, as a proportion of the average labour productivity of the economy as 
a whole, is usually higher in Third World countries than in the industrialized countries (Riddle, 1987). This finding - to which we will return later- questions the historical interpretation of Kaztman (1984), which claims that the expansion of tertiary sector employment was marked in its first phase by low levels of productivity, and that it was only in a second phase, more closely linked with industrialization, that more productive jobs were generated.

Finally, it has also been observed that also in the industrialized countries, a substantial segment of new jobs in the services sector is marked, among other things, by low levels of skills, low wages and labour instability: a tendency heightened by the decline in the demand for unskilled labour in manufacturing (Reich, 1993). It would appear that some previous trends, such as the decline in the importance of employment in personal services, are being reversed (Milkman, Reese and Roth, 1998). As a result, the occupational structure evolves in a polarized manner, with substantial growth in employment both at the bottom and at the top of the scale of skills.

It may thus be seen that in past decades there have been processes attributable to either one of the two great tendencies studied here: genuine tertiarization and spurious tertiarization. Consequently, greater disaggregation is required in their analysis. This is true both for the industrialized countries and for those of Latin America and the Caribbean, since in both groups of countries there are multiple tendencies, and although their relative weight varies, making a strict differentiation between the genuine tertiarization of the first-named countries and the spurious tertiarization of the latter is too simplistic. ${ }^{7}$ The following section presents some data on tertiary sector growth tendencies at the global level and analyses the empirical evidence on the processes of genuine or spurious tertiarization in Latin America and the Caribbean.

\section{III}

\section{A comparative view}

As we said in the previous section, the growth in the proportion of employment accounted for by tertiary activities is a worldwide process, although it is based on a heterogeneous range of dynamics. Furthermore, this process is extremely dynamic, since between 1980 and 1997 the tertiary sector increased its share of total employment from $19.4 \%$ to $26.0 \%$ in Africa, from $46.0 \%$ to $55.1 \%$ in the Americas, from $34.6 \%$ to $43.0 \%$ in Asia, and from $42.9 \%$ to $55.6 \%$ in Europe. ${ }^{8}$ For the four regions as a whole, the increase was from $34.4 \%$ to $43.6 \%$. The regional comparison, like the theories on the growing role of the tertiary sector, give grounds for assuming that there is a positive relation between the material wealth of a society and the share of that sector in GDP and employment. Figure 1 confirms the relation between the share of the tertiary sector in employment and per capita GDP. This relation is not

\footnotetext{
${ }^{7}$ It should be noted that there are also considerable divergences between countries in the regions, connected with their particular characteristics (see Gatica (1986) and Castells (1997)).

${ }^{8}$ This is a simple average of the countries in question: 50 for Africa, 29 for the Americas, 42 for Asia and 48 for Europe (calculated by the author on the basis of ILO, 1998, pp. 243-246).
}

linear, however: there is a rapid increase in the sector's share until it reaches a level of $60 \%$, with a per capita GDP of approximately US $\$ 6,000,{ }^{9}$ but from then on a slower rate of increase and subsequently a certain degree of stability around $70 \%$, as from a per capita GDP of approximately US $\$ 17,000 .{ }^{10}$

When an economy which was initially predominantly agricultural diversifies, employment in secondary and tertiary activities expands rapidly. Of the 120 countries represented in figure 1 , most are in this phase of rapid expansion: all the African countries (except for South Africa), two-thirds of the Asian countries, and half of the Latin American nations. Towards the end of this phase, when employment in the agricultural sector has already gone down markedly in relative terms, the expulsion of labour from that sector slows down, and in the following phase the

\footnotetext{
${ }^{9}$ In 1997 dollars, calculated by the purchasing power parity method (World Bank, various years).

${ }^{10}$ In the different branches of activity in the tertiary sector there is greater dispersion of the relation between share of employment and per capita GDP. See Weller (2001, pp. 38-41) and section IV.3 of this article.
} 
Four continents: Per capita gross domestic product and tertiary employment, 1997

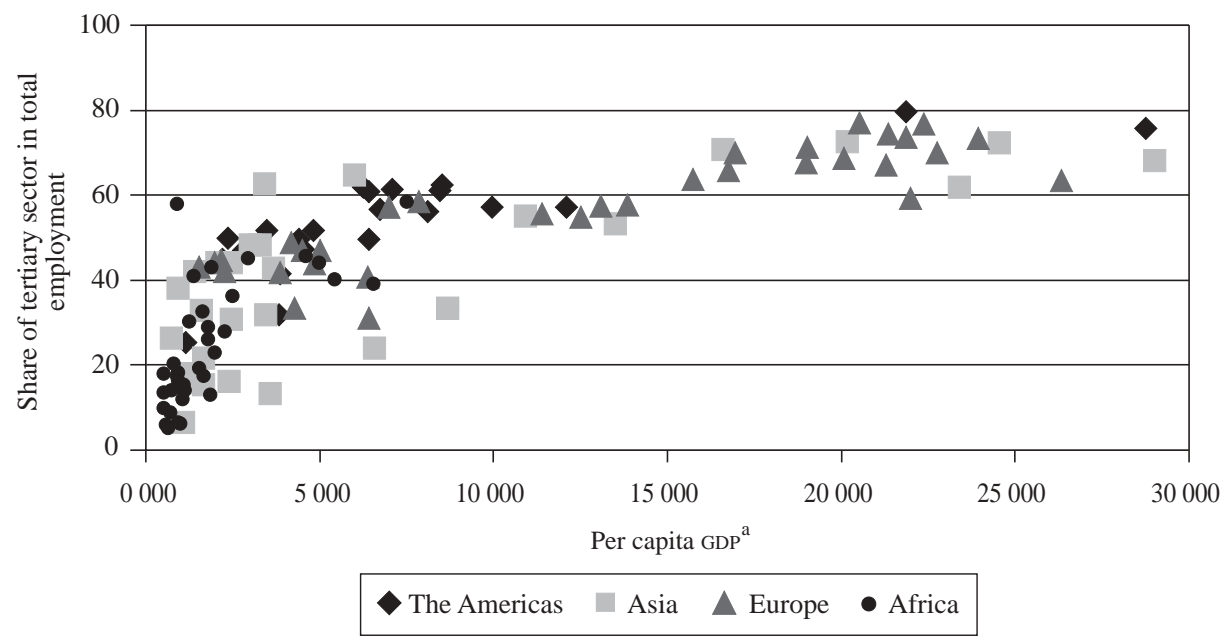

Source: Prepared by the author on the basis of data from ILO (various years) and World Bank (various years).

a In 1997 dollars, at purchasing power parity.

expansion of tertiary employment continues, but more slowly. In the countries with a high per capita GDP, agricultural employment generally only accounts for a very small proportion of total employment, so that the differences between countries depend on the relative evolution of their secondary and tertiary sectors.

Figure 1 also shows that the countries of the Americas ${ }^{11}$ have slightly higher levels of tertiary sector employment than the countries in other continents, for the same level of per capita GDP. ${ }^{12}$ Indeed, if an exponential trend line is applied, the line for the Americas is located above those for Asia and Europe and - up to a per capita GDP of approximately US\$ 7,000, which is that relevant for Africa- also above the line for the latter continent. It may be concluded that the Americas differ from the other continents in their comparatively rapid rate of tertiarization of employment. This is obviously the origin of the theory of spurious tertiarization. ${ }^{13}$

\footnotetext{
11 The data for the Americas include not only Latin America and the Caribbean but also Canada and the United States; the trends for the region do not change, however, even if the latter two countries are excluded.

12 This relatively high level is mainly due to the larger share accounted for by trade.

13 The corollary of this high share of the tertiary sector in employment is obviously the feeble generation of productive employment in agriculture and manufacturing. Figueroa (1991)
}

Is this situation reflected in the relative labour productivity of the tertiary sector? If the large share of the sector in total employment were due mainly to a spurious tertiarization process in Latin America and the Caribbean, then its average labour productivity would be below that of countries marked by genuine tertiarization. Obviously, this does not mean that the Latin American tertiary sector may not have a lower level of productivity than the industrialized countries, but this situation is due to the lower average productivity of the economy at the aggregate level rather than to a specific characteristic of the tertiary sector.

Figure 2 shows the share of the tertiary sector in employment and the GDP, for the same groups of countries. In the countries located above the $45^{\circ}$ line, the tertiary sector has a higher average level of labour productivity than the average for the economy as a whole, whereas in the other countries its productivity is below that average level. The great majority of the countries and also of the countries of each continent

examines the factors corresponding to agriculture in this respect while Berry (1976) and Tokman (1991) stress the fact that, in comparable phases of economic development, Latin American manufacturing had higher levels of productivity than the countries with early industrialization and hence less capacity to generate employment. 
FIGURE 2

Four continents: The tertiary sector's share of employment and GDP, 1997

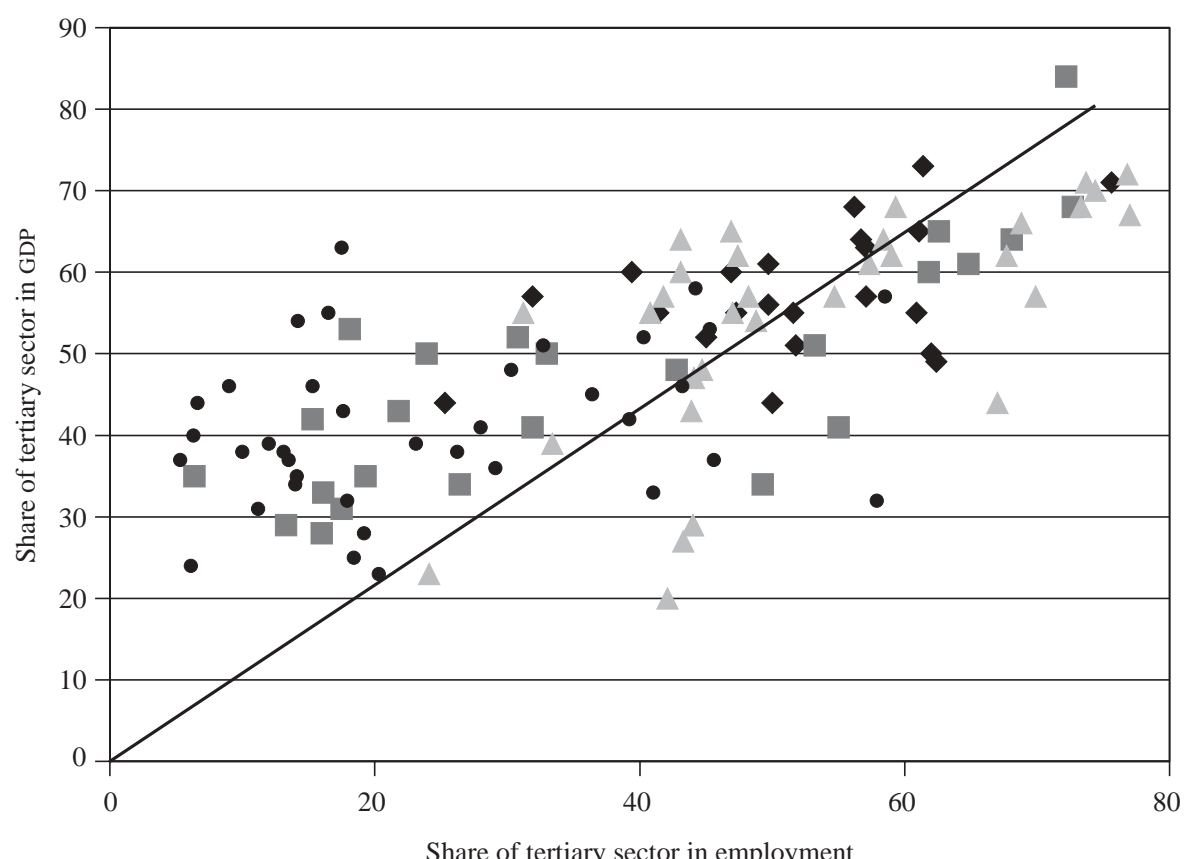

Share of tertiary sector in employment

The Americas $\square$ Asia $\triangle$ Europe $\bullet$ Africa

Source: Prepared by the author on the basis of data from ILO (various years) and World Bank (various years).

taken separately have an average level of productivity of the tertiary sector which is above the aggregate average. However, the relative labour productivity of the sector goes down in all the regions in proportion to an increase in the sector's share in employment and GDP, and for the whole set of countries it is equal to the aggregate average of the economy when a share of $57 \%$ of employment and GDP is reached.

The indices of spurious tertiarization in Latin America and the Caribbean mentioned above might give the impression that the average labour productivity of that region would tend to be lower than in other regions. However, as figure 2 shows, this is not so. The Latin American countries are in the upper part of the spectrum, slightly above the countries of other regions, and the decline in the relative productivity of the sector to the aggregate average for the economy also takes place later than in other regions: i.e., when the sector's share of employment and GDP reaches $60 \%$ of the total. Thus, although in Latin America and the Caribbean the average productivity of the tertiary sector is lower than in the industrialized countries, this productivity gap is smaller than in the other sectors, thus bringing the spurious tertiarization theory into question.

This does not mean that there may not be some elements of spurious tertiarization in the Latin American and Caribbean region, since in a context of high intra-sectoral heterogeneity a comparatively high level of average productivity may conceal a lowproductivity segment. However, of the four regions considered, Africa would appear to be that which shows the highest indices of spurious tertiarization by levels of relative productivity, since its tertiary employment growth only generates a modest increase in the sector's GDP.

In short, the Latin American and Caribbean region shows evidence of processes of both spurious and genuine tertiarization, which is hardly surprising in view of the high level of intra-sectoral heterogeneity (see section IV.3 below). On the one hand, the large share of the tertiary sector, and especially of trade, in total employment reflects the heavy weight of activities with low entry barriers and low labour productivity. On the other hand, however, the segment of employment 
corresponding to activities with high relative labour productivity linked with the dynamics of economic growth -which therefore represent genuine tertiarization - also has an impact on the aggregate data for the sector, indicating that its presence in it is substantial.

\section{IV}

\section{Tertiary sector employment in Latin America and the Caribbean}

\section{Recent trends}

Previous studies (Weller, 2000, pp. 93 et seq.) have highlighted the fact that in the 1990s most of the new jobs in the region were created in the tertiary sector. Table 1 gives updated figures on the evolution of employment by branch of activity (in the period from 1990 to 1999) in Latin America and the Caribbean and compares them with the corresponding evolution in the OECD countries.

As may be seen from the table, there is a considerable difference between the annual growth rates of employment, which are obviously greater in the case of the Latin American and Caribbean countries than in those of the OECD. Rather than reflecting a highly dynamic increase in productive employment in the first group of countries, however, this reflects the fact that the labour supply grew much more dynamically in those countries than in the OECD nations (ILO, 1998, pp. 239-242). Consequently, more interesting than the absolute levels of employment generation is the relative evolution of the different branches of activity, in which surprising coincidences may be observed, although there are also some disparities.

TABLE 1

Latin America and the Caribbean and the member countries of the Organization for Economic Cooperation and Development (OECD): Annual growth of employment and contribution of new jobs in the 1990s, by branch of activity ${ }^{\mathrm{a}}$

\begin{tabular}{|c|c|c|c|c|c|c|}
\hline & \multicolumn{4}{|c|}{ Latin American and Caribbean countries ${ }^{b}$} & \multirow{2}{*}{\multicolumn{2}{|c|}{$\frac{\text { OECD countries }^{\mathrm{c}}}{\text { Median }}$}} \\
\hline & \multicolumn{2}{|c|}{ Weighted average } & \multicolumn{2}{|c|}{ Median } & & \\
\hline & Growth & Contribution $^{\mathrm{f}}$ & Growth & Contribution $^{f}$ & Growth & Contribution $^{\mathrm{f}}$ \\
\hline Agriculture, forestry and fishing & -0.4 & -4.3 & -0.3 & -2.6 & -2.6 & -7.0 \\
\hline Manufacturing & 1.2 & 8.3 & 1.2 & 9.0 & -0.9 & -6.3 \\
\hline Construction & 2.8 & 7.8 & 3.1 & 6.5 & 1.2 & 9.2 \\
\hline \multicolumn{7}{|l|}{ Tertiary sector } \\
\hline Trade, restaurants and hotels & 4.0 & 32.7 & 5.7 & 33.8 & 2.0 & 25.9 \\
\hline Basic services $^{\mathrm{d}}$ & 4.4 & 10.8 & 4.2 & 8.9 & 0.4 & 6.3 \\
\hline $\begin{array}{l}\text { Financial services, insurance, real estate } \\
\text { and business services }\end{array}$ & 6.0 & 12.3 & 5.6 & 11.1 & 3.7 & 33.2 \\
\hline Community, social and personal services & 2.7 & 34.8 & 3.0 & 35.7 & 1.3 & 29.6 \\
\hline Others $^{\mathrm{e}}$ & -2.1 & -2.3 & -1.4 & -0.3 & -2.5 & -0.8 \\
\hline Total & 2.2 & 100.0 & 3.5 & 100.0 & 1.1 & 100.0 \\
\hline
\end{tabular}

Source: Prepared by the author on the basis of official data of the countries of Latin America and the Caribbean and data from ILO (various years) in the case of the OECD countries.

a For Latin America and the Caribbean, 1990-1999; for the OECD countries, 1990-1998.

b Up to 17 countries, depending on availability of data.

c 20 member countries before 1990 .

d Includes electricity, gas and water and transport, storage and communications.

e Mainly mining.

f Total for contributions does not always add up to 100 , because the figures are medians. 
In both groups of countries there was a contraction in employment in primary activities (agriculture and mining), and the growth of employment in manufacturing was sluggish: slightly positive in Latin America and the Caribbean and slightly negative in the OECD countries. Of the branches not belonging to the tertiary sector, in both groups of countries only construction generated employment dynamically, at rates similar to those of the generation of employment in the economy as a whole.

We thus see that in both groups of countries it was the tertiary sector which provided almost all the new jobs in the 1990s. The financial services, insurance, real estate and business services branch and the trade, restaurants and hotels branch registered the highest employment growth rates. The latter branch, in fact, contributed a third of the new jobs in Latin America and the Caribbean and a quarter in the OECD countries. There was a big difference between the contributions made by the financial services, insurance, real estate and business services branch in the two groups of countries: it was between $11 \%$ and $12 \%$ in Latin America and the Caribbean, but 33\% in the OECD countries. This clearly shows the close linkages between this branch and the current processes of technological and productive restructuring led by the most highly developed countries.

Another branch which made an important contribution to new employment was that of community, social and personal services, in which employment grew slightly less than total employment in Latin America and the Caribbean and slightly more than it in the OECD countries. The only exception to the general coincidences at the sectoral level in terms of relative employment growth was basic services, in which employment grew rapidly in the Latin American and Caribbean region, but only feebly in the OECD. ${ }^{14}$ Even so, these activities accounted for $6 \%$ of all new jobs in the OECD.

As noted in section II, some authors have asserted that in Latin America and the Caribbean a considerable part of the increase in tertiary employment in the post-war decades was linked with dynamic economic growth. Consequently, it is hardly surprising that in that period the average labour productivity of the tertiary sector amply exceeded the average for the regional

\footnotetext{
14 A possible explanation for this is the considerable reduction in employment in ports and rail transport which occurred in many OECD countries due to the modernization of these transport systems.
}

FIGURE 3

Latin America and the Caribbean: Evolution of labour productivity, 1970-2000

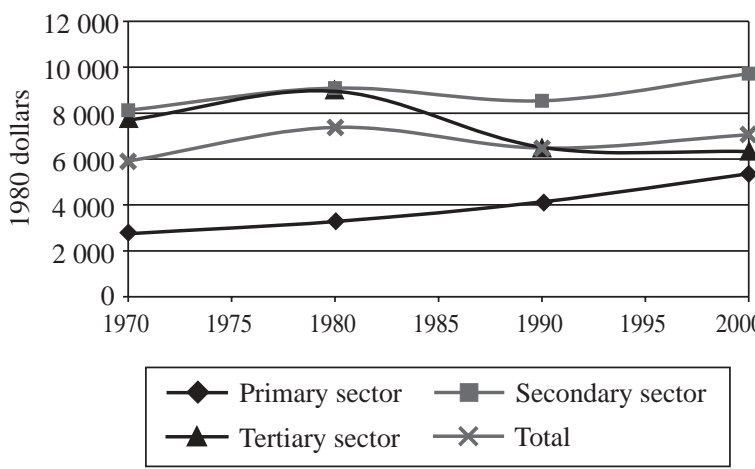

Source: Prepared by the author on the basis of data from Hofman (1999) and information from the countries.

economy as a whole (figure 3). During the 1980s crisis, the increase in the sector's share in the occupational structure became even faster, in view of the weakness of employment generation in the secondary sector and the concentration of new jobs in informal activities, many of them in the tertiary sector (Tokman, 1994). As a result, the average labour productivity of the tertiary sector fell sharply, thus interrupting the upward trend of previous decades. This decline was sharper than in the economy as a whole, and by 1990 the labour productivity of the sector had fallen to the average level of the economy as a whole.

During the 1990s, overall average labour productivity in Latin America and the Caribbean began to rise again, albeit without reaching the 1980 level. This rise, however, was concentrated in the primary and secondary sectors, whereas in the tertiary sector labour productivity continued to fall, although more slowly than in the 1980s. As a result, the average productivity of the tertiary sector fell below the average for the economy as a whole. This was due to the polarized generation of tertiary employment, with some highly productive activities generated on the one hand, ${ }^{15}$ but many more low-productivity activities on the other. The following two sections will deal with these aspects in greater detail.

\footnotetext{
${ }^{15}$ In wage-earning employment, between $80 \%$ and $95 \%$ of the most highly qualified occupational group (professionals, or professionals and technicians, depending on the information available) work in the tertiary sector. With regard to the concentration of new wageearning jobs for persons of high educational level in the tertiary sector, see Weller (2000, pp. 160-162).
} 


\section{Recent patterns of evolution: the cases of Brazil, Chile and Mexico}

Economic and production development trends strongly affect the composition and expansion of tertiary employment. In order to gain a better understanding of recent trends, this section will analyse the disaggregated evolution of tertiary employment in the 1990s in three countries of the region (Brazil, Chile and Mexico), using a slightly modified version of the methodology proposed by Browning and Singelmann (1975) and regrouping tertiary sector activities into five categories:

- Basic services: Electricity, gas and water, and communications (average educational level 10.3 years' schooling) ${ }^{16}$

- Distributive services: wholesale and retail trade, transport and storage (average educational level 7.7 years' schooling);

- Producer services: financial services, insurance, real estate and business services (average educational level 10.8 years' schooling);

- Social services: public administration, education, health, social assistance (average educational level 10.3 years' schooling);

- Personal services: restaurants and hotels, entertainment, domestic service, other personal services (average educational level 5.9 years' schooling).

There is an inverse relation between the average educational level of tertiary sector activities and their degree of informality. Thus, within the tertiary sector personal services have the highest level of informal employment, followed by distributive services. ${ }^{17}$ Consequently, the "informalization of services" detected by Klein and Tokman (2000, p. 16) is connected with the expansion of those branches. Thus, although all these activities are inherently more or less heterogeneous, ${ }^{18}$ an approximation can be made to the role played by the different services "between modernity and survival" on the basis of the average educational level, since the services with the highest educational requirements (basic, producer and social

\footnotetext{
16 The data on the average educational level in each category correspond to Brazil in 1998 and are only given by way of example; in Mexico the ratios are very similar (Weller, 2001, p. 47).

17 See, for example, the data of Pollack and Jusidman (1997) on Mexico.

${ }^{18}$ Section IV.3 below deals with some aspects of the heterogeneity of the different branches of the tertiary sector.
}

services) are connected with modernization processes, whereas those with low educational requirements (personal and distributive services) have low access barriers and hence correspond to the areas of survival employment. ${ }^{19}$ It may be noted in this respect that in the literature on this subject the expansion of producer, social and basic services is generally interpreted as the main expression of the post-industrial society, while personal services are considered to be remnants of the proto-industrial structure and an expression (at least in the case of some personal services) of the social dualism which is said to be inherent in the informationbased society. Distributive services combine activities related with dynamic change (such as transport) with others which are supposedly typical of lessindustrialized societies (Castells, 1997, pp. 241-243).

When comparing the data given in table 2 it should be borne in mind that they reflect very different macroeconomic paths, which must obviously have an impact on the evolution of employment; thus, during the periods covered by the data, the GDP grew at annual rates of 2.7\% in Brazil (1990-1998), 7.6\% in Chile (1990-1996), and 3.3\% in Mexico (1989-1998). Whereas Chile was going through an unprecedented period of economic expansion, Brazil and Mexico suffered serious crises in the early and mid 1990s, respectively. Moreover, in that decade the three countries followed different trade patterns: Mexico was becoming increasingly integrated with the United States economy, Chile was specializing in diversified exports of natural resource-based goods, and Brazil was combining the export of primary commodities with an orientation towards the regional market (Mercosur). In order to facilitate the interpretation of the data on the countries in question, table 2 also includes data on the most industrialized countries, the Group of Seven, taken from the study by Castells (1997).

An analysis of table 2 shows, broadly speaking, that in the three Latin American countries in question the share of social and producer services in employment is lower than in the G-7 countries, while that of distributive services registers similar levels and that of personal services is slightly higher, which is in keeping with the tendencies noted at the beginning of this section.

\footnotetext{
19 Although not all employment in the informal sector can be considered survival employment, there is a persistent negative correlation between economic growth and the expansion of the informal sector, which indicates that survival employment continues to predominate in that sector (see Weller, 2000, pp. 52 et seq.).
} 
Brazil, Chile, Mexico and the G-7 countries: Composition of tertiary sector employment

(As percentages of total employment)

\begin{tabular}{|c|c|c|c|c|c|c|c|c|}
\hline & \multicolumn{2}{|c|}{ Brazil } & \multicolumn{2}{|c|}{ Chile } & \multicolumn{2}{|c|}{ Mexico } & \multicolumn{2}{|c|}{ G-7 countries ${ }^{a}$} \\
\hline & 1990 & 1998 & 1990 & 1996 & 1989 & 1998 & Share $^{b}$ & Trend \\
\hline Basic services & 1.1 & 1.1 & 1.1 & 1.6 & 1.0 & 1.2 & $\ldots$ & $\ldots$ \\
\hline Distributive services & 20.5 & 21.6 & 21.8 & 21.8 & 20.2 & 22.2 & $20-25$ & Constant \\
\hline Producer services & 5.7 & 5.5 & 4.6 & 7.0 & 4.3 & 6.3 & $7-14$ & Strong upward \\
\hline Social services & 14.4 & 15.2 & 12.4 & 13.3 & 12.4 & 11.1 & $20-25$ & Upward \\
\hline Personal services & 14.4 & 16.2 & 16.1 & 15.1 & 12.0 & 14.9 & $10-14$ & Upward \\
\hline Total tertiary sector & 56.1 & 59.6 & 55.8 & 58.7 & 49.9 & 55.7 & $57-72$ & Upward \\
\hline Total & 100.0 & 100.0 & 100.0 & 100.0 & 100.0 & 100.0 & 100.0 & - \\
\hline
\end{tabular}

Source: Special tabulation of household surveys of the countries, and Castells (1997).

a Canada, France, Germany, Italy, Japan, United Kingdom, United States.

b At the beginning of the 1990s.

Coinciding with the variations in the data found by Castells for the G-7 countries, table 2 shows similarities but also important differences between the three Latin American countries. These countries register a considerable increase in the share of the tertiary sector in employment, which stood at between $56 \%$ and $60 \%$ at the end of the period. ${ }^{20}$

The dynamics vary significantly between one type of service and another. Between 1990 and 1996, a period of very high economic growth in Chile, that country displayed a pattern very similar to that of the most advanced countries: increases in the shares of the services linked most closely with modernization processes (social, producer and basic services), stagnation, albeit at a high level, in the case of distributive services, and a decline in the case of personal services, although the latter continued to have a higher share than in the G-7 countries. The expansion of employment in the tertiary sector in Chile greatly helped the tendency towards an upgrading of the occupational structure.

The evolution of employment in Brazil and Mexico, for its part, largely reflects the low growth in that period; in both countries personal and distributive services - more characteristic of survival employmentincreased their shares. In Mexico, however, the share of employment in producer services also rose, which may have been due to the heavy restructuring of

${ }^{20}$ In the case of men, this share is lower and displays almost no differences between the countries (48\%-49\%); in the case of women it is higher and also varies more between the countries $(67 \%-80 \%)$. manufacturing, from which the demand for these services might have come. In Brazil, in contrast, employment in these services remained at a stable level, while in addition to the increase in personal and distributive services there was also a rise in the share of social services, possible in response to a major social policy effort. ${ }^{21}$ Thus, in both Brazil and Mexico there were polarized processes in which an increase in survival employment prevailed, although at the same time new jobs were created in different activities requiring high levels of qualifications. ${ }^{22}$ This polarized evolution of new tertiary employment in the Latin American region during the 1990s was more marked in the case of women than in that of men. Because of the high proportion of women in tertiary activities requiring a high level of education, their labour status registered a relative improvement, in the context of a global deterioration in the labour situation and the persistence of gaps compared with men. ${ }^{23}$

\section{Employment characteristics in the different branches of activity of the tertiary sector}

Regarding many employment characteristics, the tertiary sector as a whole compares favourably with the

\footnotetext{
${ }^{21}$ Between the beginning and end of the 1990s, public social expenditure in Brazil rose from $18.1 \%$ to $21.0 \%$ of GDP, a level exceeded in Latin America only by Uruguay (ECLAC, 2001, p. 118). ${ }^{22}$ For a comparison of the patterns of employment generation in the north and south of Latin America during the 1990s, see Stallings and Weller (2001).

${ }^{23}$ See in this respect ILo (1999) and Gálvez (2001).
} 
Latin America and the Caribbean: Employment characteristics of the different branches of the tertiary sector

(Schematic presentation)

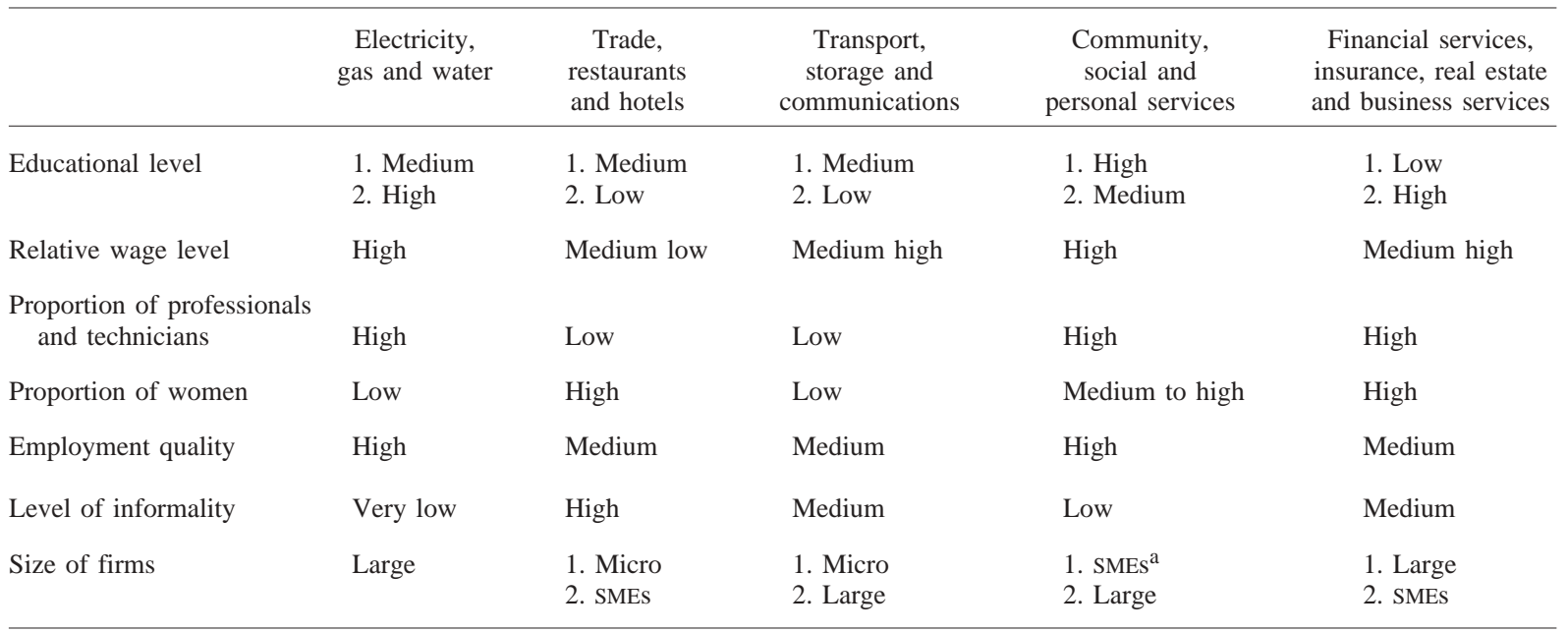

Source: Weller (2001), pp. 69-84.

a SMEs: small and medium-sized enterprises.

whole of economic activities, above all because of labour conditions in agriculture and construction (Weller, 2001, pp. 69-84). As noted in the previous analysis, however, there is great heterogeneity within the sector. Thus, the five branches of activity of the tertiary sector display considerable differences, shown schematically in table 3 . These refer to educational level, wage levels, the proportion of professionals and technicians, the proportion of women, non-wage indicators of the quality of employment, the level of informality, and the prevailing patterns as regards the size of the firms in the different branches. If a branch has high levels of educational requirements and wage and non-wage employment quality, as well as a high proportion of professionals and technicians, this indicates that it is closely related with production modernization processes. In contrast, low levels of these indicators coincide with high levels of informality. The proportion of women employed has to do both with the recent increase in the demand for female labour, concentrated in some tertiary activities, and with the high share of informal tertiary employment in the occupational structure, especially of women of low educational level; the patterns of enterprise size also indicate some restructuring tendencies related with the greater or lesser expansion of the branches concerned.
The summary given in table 3 highlights the great heterogeneity of the tertiary sector. Since for reasons of space it is not possible to review the main characteristics of each of the branches, ${ }^{24}$ the main tendencies influencing the expansion of employment in them will be analysed below. ${ }^{25}$

a) Financial services, insurance, real estate and business services

This is the branch of the tertiary sector whose evolution is most closely correlated with economic growth (Weller, 2001, pp. 40-41). Business support services have the highest weight in it and display dynamic processes of specialization and expansion. The present trend of a growing number of firms to concentrate their activities in the areas in which they have competitive advantages and to purchase other goods and services in one way or another from other suppliers has brought with it an increase in the demand for specialized services. In this context, many completely new activities have arisen, especially in the area of information technology, while others have

${ }^{24}$ For the quantitative information on which table 3 is based, see Weller (2001, pp. 69-84).

${ }^{25}$ For the growth of employment in each branch, see table 1. 
grown in relative importance (publicity, for example). Sometimes the appearance of new enterprises has been accompanied by the closure of units in the purchasing companies, which have preferred to contract the corresponding services from specialized firms. This explains the strong presence of small and mediumsized enterprises (SMEs) in this branch, in which they even outnumber large firms. Although the performance of many firms in this branch is sensitive to the prevailing economic conditions, ${ }^{26}$ it may be assumed that the business services category will continue to be a dynamic source of employment in the future.

In the case of financial services, another important activity in this branch, the simultaneous tendencies towards a strong expansion (including the development of new products) and labour-saving modernization, often in the context of processes of consolidation of the financial system, had less favourable implications for employment, especially in countries with a traditionally highly protected financial sector which was recently subjected to measures aimed at achieving greater openness. ${ }^{27}$ Even so, financial services, insurance, real estate and business services were the branch, taken as a whole, where employment grew most in the 1990s. This is important, because within the tertiary sector this is also the branch which displays the best quality indicators in terms of educational levels, wages, non-wage job quality, etc. Both the internal transformation of this branch and its marked expansion were factors that resulted in strong demand for staff of high or intermediate educational level.

\section{b) Basic services}

These services include the electricity, gas and water branch and the transport, storage and communications branch.

In the 1990s, many countries modernized their electricity, gas and water and communications services. This process often took place in the context of privatization operations, which were generally accompanied by reductions in staff. On the other hand, the expansion of infrastructure and the rapid

\footnotetext{
26 This is reflected in the heavy loss of jobs in firms of the "new economy" in 2000 and 2001, especially in the United States. In those years, employment in this branch shrank in Latin America, too (ECLAC, various years).

27 At the global level, the technological and organizational changes which took place in the $1990 \mathrm{~s}$, together with processes of concentration, led to a drop in employment in the financial sector (ILO, 2001a).
}

incorporation of new technologies and services helped to generate new jobs, often of quite high quality and requiring persons with a high educational level. At all events, however, this branch contributed relatively little to the generation of employment, because of its small size.

In the transport, storage and communications branch, transport accounts for the bulk of the jobs. The modernization of the transport infrastructure, which helped to further internal geographical integration, also favoured employment, especially in surface transport. The greater incorporation in the world economy and its impact on the expansion of foreign trade, together with the increase in purchasing power and the boost for domestic trade, also supported the generation of employment in this activity. On the other hand, in areas such as ports and rail transport, modernization processes, often linked with privatization, resulted at least temporarily in reductions in staff.

The composition of this branch (classified at the single-digit level of the ISIC ${ }^{28}$ is heterogeneous, because the occupational structure differs a great deal between transport and storage, on the one hand, and communications, on the other. Reflecting this heterogeneity, most of the employment in the branch is in micro-enterprises or large enterprises. In transport, there is an intermediate level of informality, although many of the corresponding activities cannot be considered as survival employment, because they require a certain amount of capital.

\section{c) Community, social and personal services}

These services form the largest and most heterogeneous branch of the tertiary sector, and in the 1990 s they were the least dynamic in terms of employment growth (table 1). This was due largely to the smaller share of employment accounted for by the public sector, which is heavily represented in this branch. ${ }^{29}$ Even so, this branch contributed a large percentage of the new jobs created, due partly to the increase in social expenditure in the decade in question, which favoured the main social services, such as education and health, and had an impact on both public and private employment. In this case, the new jobs were mostly of good quality, for persons of high

\footnotetext{
${ }^{28}$ ISIC: International Standard Industrial Classification.

${ }^{29}$ In the region as a whole, the public sector's share of urban employment went down from $15.5 \%$ in 1990 to $13.0 \%$ in 2000 , with most of this decline being concentrated in the first half of the decade (ILO, 2001b, p. 61).
} 
educational level (Weller, 2000, pp. 164 and 165). The improvement in income levels, together with changes in lifestyles and social life, also helped to increase the demand for certain community services (such as gymnasiums, swimming pools, tourist services, etc.). The growing income inequality and greater social segmentation stimulated the demand for labour for the provision of personal, household and community services, ranging from domestic service to gardeners, apartment building janitors and private security services. Some of these occupations are marked by low wages and poor non-wage quality. A significant part of the growth in the informal sector is concentrated in this branch, above all in personal services.

\section{d) Trade, restaurants and hotels}

Generally speaking, this branch — which is the third largest in Latin America and the Caribbean after community, social and personal services and the agricultural sector, and which generated almost a third of all new jobs in the 1990s - creates jobs with the most unfavourable characteristics in the tertiary sector, but even so it represents an important option for persons with intermediate and low educational levels; by and large, the wage employment it offers compares favourably with the agricultural sector and construction.

The expansion in employment in this branch during the 1990s came from various sources. First, trade in general, as an activity with low entry barriers, reflected the weakness of aggregate demand for labour,

\section{V}

\section{Conclusions}

The tertiary sector occupies an increasingly dominant place in the economic structure because of its growing importance not only in the generation of value added and employment but also in the field of support for enterprises in other sectors, due to the growing contribution of services to systemic competitiveness. Services also contribute to the accumulation of human capital, which is a key factor for improving productivity and long-term economic growth. Thus, the greater concern to satisfy basic social needs (education, health, care of the elderly, pre-school attention) stimulates the demand for services, many of which and in many countries there was an increase in informal activities such as street vendors $;^{30}$ because of this, the correlation between the share of this branch in total employment and the relative wealth of the corresponding economy is very weak (Weller, 2001, pp. 38-41). Second, wholesale trade was favoured by the greater economic openness, which gave a strong boost to exports and imports. Third, in the retail trade segment -which is much more important in terms of employment - there was an increase in demand due to the growth of real wages in the formal sector, the expansion of consumer credit, and the fall in the prices of some goods due to the greater trade openness. Fourth, this greater openness also gave a boost to supply by expanding the range of products available. Fifth, within this context retail trade underwent considerable changes, the most outstanding of which was the appearance of large-scale establishments such as supermarkets, hypermarkets and large covered shopping centres (malls), which were an influence in the "consumer culture" of the population, stimulating demand through the imitation effect. Sixth, the spread of bigger establishments created considerable competition for smaller establishments, so that in many countries employment in very small commercial enterprises grew only feebly. Finally, employment in the other major segment of this branch - hotels and restaurants - was favoured, like trade, by greater domestic demand and also shared in the expansion of tourism as an export service, which is increasingly important in a number of countries of the region.

have traditionally been provided by the public sector but are now increasingly being supplied by private enterprise.

At the other extreme - because of the low entry barriers, especially in trade and personal services - the tertiary sector also includes the main activities which

\footnotetext{
30 In Brazil and Mexico, around $15 \%$ of all jobs created in the 1990s corresponded to own-account (excluding professionals and technicians) or unpaid work in the trade, restaurants and hotels branch. This segment has the lowest educational levels of the whole tertiary sector (Weller, 2001, pp. 56-64).
} 
allow segments of the population that are excluded from the dynamic areas of production to find employment for themselves. These segments include both those who do not have the qualifications required in the labour market and also new entrants to that market and persons who have lost their jobs.

With regard to Latin America and the Caribbean, it has been claimed that the big expansion in tertiary sector employment in that region reflects a spurious form of tertiarization in which low-productivity, poorly paid jobs prevail, and that this form of tertiarization is structurally different from the "genuine tertiarization" of the industrialized countries, which are becoming "post-industrial" societies. A comparison between the four continents examined in this article does provide some support for this theory, because of the large share of the tertiary sector in total employment, taking into account the level of income of the region. On the other hand, the fact that the average labour productivity of the sector is high in relative terms would appear rather to indicate a considerable presence of activities linked with modernization process and thus reflect genuine tertiarization. Consequently, although part of the expansion of tertiary sector employment is due to the low level of generation of employment in other sectors and labour supply pressures, this is not a decisive factor in the characteristics of the sector as a whole.

When talking about tertiarization in Latin America and the Caribbean, it is important always to bear in mind the simultaneous presence of both the spurious and genuine forms, in order to avoid inappropriate over-simplifications such as identifying tertiarization with informality or interpreting it exclusively as an expression of post-industrial modernization. Within the heterogeneity of the tertiary sector, historically activities linked with social and productive development have expanded to a greater or lesser extent according to the characteristics of the prevailing form of growth, whereas low-productivity employment has displayed an anti-cyclical pattern and has mainly increased in periods of low economic growth.

With regard to the 1990s (updating the periodization developed by Oliveira and Ariza (1998)), the evolution of tertiary employment in that decade may be summarized by saying that in the phase of reforms and greater economic openness the demand for producer services and distributive services increased, while the share of social and personal services in tertiary employment went down in relative terms, although they still grew substantially in absolute terms. In this context, the generation of employment in the sector was marked by multiple simultaneous processes of inclusion and exclusion of labour. ${ }^{31}$

These simultaneous processes were visible above all in the polarized generation of tertiary employment. On the one hand, during the 1990s some branches with favourable labour characteristics grew much more than others, in both the tertiary and other sectors. On the other hand, many of the new tertiary sector jobs generated were in low-productivity activities with unfavourable labour characteristics.

This polarization was also reflected in the characteristics of labour demand, which was biased in favour of staff of high educational level, and in the expansion of occupations demanding the highest qualifications. This could be a positive trend which would favour merit-based social mobility, since many occupations in the sector are characterized by strong demand for human capital not closely associated with high capital density. However, the high degree of segmentation of the educational system in many countries of the region could restrain the spread of this positive trend. Moreover, the weak demand for persons of low educational level has obliged many of them to try to find survival employment for themselves in activities with low entry barriers.

The labour polarization in the tertiary sector has been particularly marked in the case of women. The high and growing proportion of women in that sector and the overall expansion of the sector has favoured the incorporation of the growing female labour supply in productive activities. The demand for labour has been strongly biased towards women with intermediate or high levels of education, however, whereas less qualified women have had serious difficulties in finding good-quality employment.

(Original: Spanish)

\footnotetext{
${ }^{31}$ For an analysis of this concept, see Weller, 2001, pp. 13-20.
} 
Altenburg, T., R. Qualmann and J. Weller (2001): Modernización económica y empleo en América Latina: propuestas para un desarrollo incluyente, "Macroeconomía del desarrollo" series, No. 2, LC/L.1512-P, Santiago, Chile, Economic Commission for Latin America and the Caribbean (ECLAC). United Nations publication, Sales No. S.01.II.G.51.

Appelbaum, H. and R. Schettkat (1995): El empleo y la productividad en las economías industriales, Revista internacional del trabajo, vol. 114, No. 4-5, Geneva, International Labour Organization (ILO).

Baumol, W.J. (1985): Productivity policy and the service sector, in R.P. Inman, Managing the Service Economy: Prospects and Problems, Cambridge, Cambridge University Press.

Bell, D. (1973): The Coming of Post-Industrial Society: A Venture in Social Forecasting, New York, Basic Books.

Berry, A. (1976): Una interpretación positiva del papel desempeñado por el sector terciario en la incorporación de los inmigrantes a la economía urbana, in R. Cardona Gutiérrez (ed.), Colombia: distribución espacial de la población, Bogotá, D.C., Canal Ramírez-Antares.

Bhagwati, J. (1987): International trade in services and its relevance for economic development, in O. Giarini (ed.), Emerging Service Economy, Oxford, Pergamon Press.

Browning, H.L. and J. Singelmann (1975): Emergence of a Service Society: Demographic and Sociological Aspects of the Sectoral Transition of the Labor Force in the USA, Austin, University of Texas.

Carneiro, F.G. (1994): Informalidade e terceirização: duas tendencias opostas?, Revista de economia política, vol. 14, No. 4 (56), São Paulo.

Castells, M. (1997): La era de la información: economía, sociedad y cultura, Madrid, Alianza Editorial.

De Oliveira, O. and M. Ariza (1998): Terciarización, feminización de la fuerza de trabajo y precariedad laboral en México, in I. Arriagada and C. Torres (eds.), Género y pobreza: nuevas dimensiones, Santiago, Chile, Isis Internacional.

ECLAC (Economic Commission for Latin America and the Caribbean) (various years): Economic Survey of Latin America and the Caribbean, Santiago, Chile.

(2001): Social Panorama of Latin America, 2000-2001, LC/G.2138-P, Santiago, Chile, September. United Nations publication, Sales No. E.01.II.G.141

Echeverría, R. (1985): Empleo público en América Latina, Investigaciones sobre empleo, No. 26, Santiago, Chile, Regional Employment Programme for Latin America and the Caribbean (PREALC)

Economía industrial (1997): No. 313, Madrid, Ministry of Science and Technology.

Figueroa, A. (1991): Desarrollo agrícola en la América Latina, in O. Sunkel (ed.), El desarrollo desde dentro: un enfoque neoestructuralista para la América Latina, Mexico City, Fondo de Cultura Económica.

Gálvez, T. (2001): Aspectos económicos de la equidad de género, "Mujer y desarrollo" series, No. 35, LC/L.1561-P, Santiago, Chile, Economic Commission for Latin America and the Caribbean (ECLAC). United Nations publication, Sales No. S.01.II.G.107

Gatica, J. (1986): Evolución del empleo formal e informal en el sector servicios latinoamericano, Working paper No. 279, Santiago, Chile, Regional Employment Programme for Latin America and the Caribbean (PREALC).

Gershuny, J. (1987): The future of service employment, in O. Giarini, Emerging Service Economy, Oxford, Pergamon Press.

Gestión (1998): Se busca especialista, Santiago, Chile, July.

Giarini, O. (ed.) (1987): Emerging Service Economy, Oxford, Pergamon Press.
(1995): Some considerations on the future of work: redefining productive work, in M. Simai (ed.), Global Employment: an International Investigation into the Future of Work, London, Zed Books.

Hofman, A. (1999): Productividad y crecimiento en América Latina: una versión comparativa a largo plazo, LC/R.1947, Santiago, Chile, Economic Commission for Latin America and the Caribbean (ECLAC).

ILO (International Labour Organization) (various years): Yearbook of Labour Statistics, Geneva.

(1998): World Labour Report, 1998-1999, Geneva.

(1999): Panorama laboral, 1999, Lima.

(2001a): La incidencia en el empleo de las fusiones y adquisiciones en el sector de los servicios financieros y de la banca, Geneva.

(2001b): Panorama laboral, 2001, Lima.

Kaztman, R. (1984): Sectoral transformations in employment in Latin America, CEPAL Review, No. 24, LC/G.1324, Santiago, Chile, December.

Klein, E. and V. Tokman (2000): Social stratification under tension in a globalizad era, CEPAL Review, No. 72, LC/G.2120-P, Santiago, Chile, December.

Krüger, H. (1999): Personenbezogene Dienstleistungen: ein expandierender Arbeitsmarkt mit sieben Siegeln, Bremen, Universität Bremen, unpublished.

Milkman, R., E. Reese and B. Roth (1998): A macro-sociologia do trabalho doméstico remunerado, Revista latinoamericana de estudios del trabajo, year 4, No. 7, Buenos Aires, Asociación Latinoamericana de Sociología del Trabajo (ALAST).

Pieper, U. (2000): Deindustrialization and the social and economic sustainability nexus in developing countries: cross-country evidence on productivity and employment, The Journal of Development Studies, vol. 36, No. 4, London, Frank Cass.

Pinto, A. (1984): Metropolization and tertiarization: structural distortions in Latin American development, CEPAL Review, No. 24, LC/G.1324, Santiago, Chile, December.

Pollack, M. and C. Jusidman (1997): El sector informal urbano desde la perspectiva de género. El caso de México, "Mujer y desarrollo" series, No. 20, LC/L.1017, Santiago, Chile, Economic Commission for Latin America and the Caribbean (ECLAC).

Ramos, J. (1984): Urbanization and the labour market, CEPAL Review No. 24, LC/G.1324, Santiago, Chile, December.

Reich, R.B. (1993): El trabajo de las naciones: hacia el capitalismo del siglo XXI, Buenos Aires, Vergara.

Riddle, D.I. (1987): The role of the service sector in economic development: similarities and differences by development category, in O. Giarini (ed.), Emerging Service Economy, Oxford, Pergamon Press.

Rubalcaba Bermejo, L. (1997): Servicios a empresas: marco analítico, magnitud y evolución reciente en Europa, Economía industrial, No. 313, Madrid, Ministry of Science and Technology.

Ryten, J. (1999): Service sector statistics, LC/R.1889(Sem.88/3), Santiago, Chile, Economic Commission for Latin America and the Caribbean (ECLAC)

Stallings, B. and J. Weller (2001): Employment in Latin America: cornerstone of social policy, CEPAL Review, No. 75, LC/G.2150-P, Santiago, Chile, December.

Tokman, V.E. (1991): Mercados de trabajo y empleo en el pensamiento económico latinoamericano, in O. Sunkel (ed.), El desarrollo desde dentro: un enfoque neoestructuralista para la América Latina, Mexico City, Fondo de Cultura Económica.

(1994): Generación de empleo en un nuevo contexto estructural, Santiago, Chile, International Labour Organization (ILO). 
Verdera, F. (1994): El mercado de trabajo de Lima Metropolitana: estructura y evolución, 1970-1990, Documento de trabajo, No. 59, Lima, Instituto de Estudios Peruanos (IEP).

Weller, J. (2000): Reformas económicas, crecimiento y empleo: los mercados de trabajo en América Latina, Santiago, Chile, Economic Commission for Latin America and the Caribbean (ECLAC)/ Fondo de Cultura Económica.

(2001): Procesos de exclusión e inclusión laboral: la expansión del empleo en el sector terciario, "Macroeconomía del desarrollo" series, No. 6, LC/L.1649-P, Santiago, Chile, Economic Commission for Latin America and the Caribbean
(ECLAC), December. United Nations publication, Sales No. S.01.II.G.187.

Wieczorek, J. (1995): Movimientos intersectoriales en el empleo mundial y agrandamiento del sector de los servicios, Revista internacional del trabajo, vol. 134, No. 2, Geneva, International Labour Organization.

Willke, G. (1999): Die Zukunft unserer Arbeit, Frankfurt, Campus Verlag.

World Bank (various years): World Development Report, Washington, D.C. 